\title{
PERILAKU PROSOSIAL MASYARAKAT TERHADAP LANJUT USIA TERLANTAR DI KELURAHAN SINDANG JAYA KECAMATAN MANDALAJATI KOTA BANDUNG
}

\author{
Vicensia Sherly Novita Lase \\ Politeknik Kesejahteraan Sosial Bandung, vicensysherlylase@gmail.com \\ Dede Kuswanda \\ Politeknik Kesejahteraan Sosial Bandung, dede_stks@yahoo.co.id \\ Endah Dwi Winarni \\ Politeknik Kesejahteraan Sosial Bandung, endah_dwiwinarni@yahoo.co.id
}

\begin{abstract}
The research about "Prosocial Behaviour of People To Neglected Elderly In Sindang Jaya Village of Mandalajati Subdistrict at Bandung City”. Empirically about respondent character, helping behaviour, feeling sharing behaviour, cooperation behaviour, contribution behaviour and paying attention for other welfare behaviour of people to neglected elderly. This research is using descriptive method with quantitative approachment. The technique for sample withdrawal is using stratified random sampling. The population in this study is the community in Sindang Jaya Village, namely the head of the family $(\mathrm{KK})$. And the sample or respondents in this study are people who live in the same $R W$ area with neglected elderly consisting of 43 heads of families (KK). Technique for data gathering used are questionare and documentation studies. The data analysis technique used descriptive statistical analysis. Validity testing uses face validity. Measuring instrument uses rating scale. The result of research finds that prosocial behaviour of pepole in Sindang Jaya Village overall is in high category based on the scores obtained through the questionnaire. But there is one more less aspect that is cooperation. The program which is suggested is "Increasing Prosocial Behaviour In Welfare Making For Elderly In Sindang Jaya Village". Kind of activity held to is social counseling and formatting a Lovely Quran Recitation Group for elderly in Sindang Jaya Village.
\end{abstract}

Keywords:

Prosocial Behaviour, People, Neglected Elderly

\begin{abstract}
Abstrak
Penelitian mengenai "Perilaku Prososial Masyarakat Terhadap Lanjut Usia Terlantar di Kelurahan Sindang Jaya Kecamatan Mandalajati Kota Bandung”. Penelitian ini bertujuan untuk memperoleh gambaran secara empiris mengenai karakteristik responden, perilaku menolong, perilaku berbagi rasa, perilaku kerjasama, perilaku menyumbang dan perilaku memperhatikan kesejahteraan orang lain oleh masyarakat terhadap lanjut usia terlantar. Penelitian ini menggunakan metode deskriptif dengan pendekatan kuantitatif. Teknik penarikan sampel menggunakan stratified random sampling. Populasi dalam penelitian
\end{abstract}


ini adalah masyarakat di Kelurahan Sindang Jaya yaitu kepala keluarga (KK). Dan yang menjadi sampel atau responden dalam penelitian ini adalah masyarakat yang hidup dalam wilayah RW yang sama dengan dengan lanjut usia terlantar terdiri dari 43 Kepala Keluarga (KK). Teknik pengumpulan data yang digunakan adalah angket, dan studi dokumentasi. Teknik analisi data menggunakan analisis statistik deskriptif. Pengujian validitas menggunakan uji validitas muka (face validity) Adapun alat ukur yang digunakan adalah rating scale. Hasil penelitian yang diperoleh menunjukkan bahwa perilaku prososial masyarakat terhadap lanjut usia terlantar di Kelurahan Sindang Jaya secara keseluruhan berada dalam kategori tinggi berdasarkan skor yang diperoleh melalui kuesioner. Namun terdapat satu aspek yang masih kurang yaitu perilaku kerjasama. Program yang diusulkan adalah "Peningkatan Perilaku Prososial untuk Kesejahteraan Lanjut Usia di Kelurahan Sindang Jaya". Bentuk kegiatan yang dilaksanakan adalah penyuluhan sosial dan pembentukan kelompok pengajian cinta lanjut usia di Kelurahan Sindang Jaya.

\section{Kata Kunci:}

Perilaku Prososial, Masyarakat, Lanjut Usia Terlantar 


\section{PENDAHULUAN}

Individu dihadapkan pada beberapa tahapan proses perkembangan, yaitu perkembangan masa balita, perkembangan masa anak-anak, perkembangan masa remaja, dan perkembangan masa dewasa akhir. Kehidupan dewasa akhir merupakan tahapan memasuki usia tua (old age) yang ditandai dengan individu memasuki usia 60 tahun (Hurlock, 2012). Menurut UndangUndang Republik Indonesia No. 13 Tahun 1998 tentang Kesejahteraan Lanjut Usia, mendefenisikan lanjut usia sebagai seseorang yang berusia 60 (enam puluh) tahun ke atas. Lanjut usia merupakan proses penuaan yang terjadi seiring dengan bertambahnya usia individu yang ditandai dengan menurunnya fungsi otak, jantung, hati, ginjal dan organ tubuh lainnya, serta hilangnya jaringan aktif tubuh berupa penuaan meningkat. Otot-otot tubuh. Lanjut usia dipandang bukan sebagai sebuah penyakit, walaupun ditandai dengan penurunan kemampuan tubuh untuk menyesuaikan dengan stres yang ditimbulkan oleh lingkungan (Lilik Azizah: 2011). Kondisi seperti ini sangat alamiah terjadi karena adanya perubahan fisik dan tingkah laku ketika mereka mencapai usia tahap perkembangan kronologis tertentu. Selain itu munculnya berbagai penyakit bahkan kematian juga sangat berpotensi pada lanjut usia.

Pasal 1 Ayat 3 Undang-Undang Nomor 13 Tahun 1998 tentang Kesejahteraan Lansia membedakan golongan lanjut usia berdasarkan kemampuannya dalam menjalani kehidupan lanjut usia, yaitu lanjut usia potensial dan lanjut usia terlantar. Lansia potensial adalah mereka yang telah mencapai usia 60 tahun dan masih mampu melakukan pekerjaan atau kegiatan yang menghasilkan barang dan jasa untuk memenuhi permintaan. Sedangkan lanjut usia terlantar adalah mereka yang telah mencapai usia 60 tahun tetapi memiliki keterbatasan kemampuan fisik, intelektual, emosional dan sosial, yang akan mengganggu interaksi sosial dan pemenuhan kebutuhan hidup, sehingga bergantung dengan orang lain. Sejalan dengan UU No. 13 Tahun 1998 tentang lanjut usia terlantar terdapat Peraturan Menteri Sosial Nomor 08 Tahun 2012 yang menyatakan bahwa lanjut usia terlantar merupakan salah satu Penyandang Masalah Kesejahteraan Sosial (PMKS). Lanjut usia terlantar dikatakan PMKS karena memiliki kehidupan yang kurang layak secara kemanusian dan tidak dapat memenuhi kebutuhan pokoknya baik secara rohani, jasmani dan sosial.

Jumlah lanjut usia di Indonesia menurut Badan Pusat Statistika (BPS) tahun 2020 mencapai 26,82 juta jiwa setara dengan 9,92\% dari seluruh penduduk Indonesia. Persebaran lanjut usia dilihat dari tipe daerah didominasi oleh daerah perkotaan sebesar $52,95 \%$ sedangkan di daerah pedesaan sebesar 47,05\%. Jumlah penduduk lanjut usia di Indonesia mayoritas perempuan sebesar 52, 29\%, dan laki-laki sebesar 47, $71 \%$. Selanjutnya dilihat dari kelompok umur, lanjut usia di Indonesia mayoritas berada pada usia muda (60- 69 tahun) sebesar $64,29 \%$, usia madya (70-79 tahun) sebesar $27,23 \%$ dan usia tua (80 tahun ke atas) sebesar 8,49\% (https://bps.go.id). Provinsi Jawa Barat merupakan salah satu daerah dengan jumlah penduduk lanjut usia terbanyak di Indonesia mencapai 11,12 juta jiwa setara dengan 10,05\% dari jumlah keseluruhan penduduk Jawa Barat 
(https://jabar.bps.go.id).

Permasalahan yang dialami oleh lanjut usia pada umumnya berkaitan dengan kesehatan, ekonomi, sosial dan politik. Menurut Sekjen Kemenkes, drg. Oscar Primadi, MPH mengatakan bahwa permasalahan kesehatan merupakan masalah utama yang dialami oleh lanjut usia karena kemunduran fisik. Selain permasalahan tersebut, lanjut usia juga mengalami masalah seperti kehilangan keluarga, tekanan dari orang yang lebih muda, diabaikan dan ditinggalkan oleh keluarganya sehingga merasa kesepian dan putus asa, sulit dalam melakukan aktivitas sehari hari, dan memenuhi kebutuhannya. Lanjut usia juga sering menjadi korban kejahatan dan mengalami kekerasa dari keluarga karena dianggap lemah, tidak berdaya dan tidak berguna lagi. Melihat permasalahan yang dialami oleh lanjut usia pemerintah membuat program-program yang dapat menunjang kesejahteraan bagi lanjut usia.

Program pemerintah yang dilaksanakan untuk meningkatkan kesejahteraan lanjut usia antara lain bakti sosial di dalam dan di luar panti asuhan, perlindungan sosial seperti (ASLUT), bantuan sosial seperti kelompok usaha bersama (KUBE), usaha ekonomi produktif (UEP), dan pemberian makanan dan layanan tambahan. (PMT), Puskesmas dan Rumah Sakit Ramah Lansia, serta aksesibilitas sarana dan prasarana umum seperti jalan kursi roda, jalan rotan, pintu, tangga, lift untuk gedung bertingkat, dan penyeberangan pejalan kaki. Salah satu daerah yang mengambil sikap ramah terhadap lansia adalah Kota Bandung

Peraturan daerah Kota Bandung
Tahun 2020, menyatakan bahwa Kota ramah lanjut usia adalah kota yang dapat mendorong penuaan aktif melalui optimalisasi kesehatan, partisipasi, dan jaminan dalam meningkatkan kualitas hidup sampai masa tua. Hal ini ditunjukkan dengan adanya fasilitas-fasilitas umum ramah lanjut usia seperti, taman lanjut usia, transportasi umum yang ramah lanjut usia, penyediaan panti lanjut usia, fasilitas rumah sakit khusus lanjut usia, program minggu lansia dan peraturan-peraturan lain yang pro dengan lanjut usia.

Akan tetapi, program yang dijalankan oleh pemerintah tidak sepenuhnya membantu permasalahan yang dihadapi oleh lanjut usia. Terutama permasalahan kehilangan keluarga, diabaikan oleh keluarga, kesepian, pemenuhan kebutuhan sehari-hari, melakukan aktivitas sehari-hari serta mengakses layanan, dan tekanan dari lingkungan sekitar. Sehingga perhatian masyarakat juga sangat penting untuk membantu kesejahteraan lanjut usia karena keberadaan lanjut usia di masyarakat tidak dapat diabaikan. Status sosial lanjut usia dalam kehidupan bermasyarakat dipengaruhi oleh berbagai faktor yaitu keberagaman budaya, agama, ras, dan suku. Sedangkan lanjut usia memiliki hak kehidupan yang sama sepertimanusia lainnya.

Peran masyarakat telah di atur dalam Undang-undang Nomor 13 Tahun 1998 Pasal 22 menyatakan bahwa masyarakat memiliki kesempatan seluas-luasnya dalam peningkatan kesejahteraan lanjut usia. Pernyataan ini didukung oleh Pasal 24 bahwa pemerintah memberi penghargaan terhadap peran masyarakat tersebut sesuai dengan ketentuan. Hal ini mengindikasikan 
secara jelas bahwa pemerintah membutuhkan masyakarakat sebagai kaki tangan untuk memastikan adanya perlindungan sosial terhadap lanjut usia. Peran masyarakat yang diharapkan terhadap perlindungan bagi lanjut usia terlantar salah satu adalah perilaku prososial.

Menurut Staub (Dayakisni 2009), perilaku prososial adalah perilaku yang mengandung unsur tindakan menolong yang dilakukan dengan tidak menuntut keuntungan pada pihak pelaku, tindakan tersebut dilakukan dengan kesukarelaan serta berakhir dengan terciptanya kebaikan. Mussen (2008) mengatakan bahwa perilaku masyarakat dapat dikatakan prososial apabila mampu menolong lanjut usia yang berada dalam kesulitan; mampu berbagi perasaan baik perasaan suka maupun duka dengan lanjut usia; masyarakat juga mampu bekerjasama baik dengan lanjut usia maupun orang lain untuk hal yang membantu dan menguntungkan lanjut usia; masyarakat memiliki kesediaan mendonasikan materi terhadap lanjut usia; dan masyarakat memberikan yang terbaik untuk menjamin kesejahteraan lanjut usia.

Masyarakat di Kelurahan Sindang Jaya cenderung kurang peduli dan perhatian kepada lanjut usia terlantar. Kondisi ini disebabkan oleh adanya kesibukan masyarakat dalam bekerja sehingga tidak memiliki waktu luang untuk bertindak prososial dengan lanjut usia terlantar. Masyarakat kelurahan Sindang Jaya juga cenderung membiarkan lanjut usia mengakses layanan yang ia butuhkan dan upaya peningkatan kesejahteraan lanjut usia pun tidak berjalan dengan baik karena pengetahuan masyarakat mengenai hak dan kebutuhan lanjut usia masih kurang. Dalam kondisi ini, masyarakat menjadi lingkungan yang diharapkan melindungi, membantu dan memperhatikan lanjut usia. Perilaku prososial masyarakat dapat menjadi salah satu kebutuhan lanjut usia untuk membantu kehidupannya.

Berdasarkan hasil penjajagan di lokasi penelitian terdapat 10 orang lanjut usia terlantar. Permasalahan lanjut usia terlantar di Kelurahan Sindang Jaya yaitu kesulitan melakukan aktivitas sehari-hari karena keterbatasan fisik, misalnya badan yang sudah membungkuk, penglihatan yang sudah mulai kabur,lumpuh atau tidak bisa berjalan, pendengaran yang terganggu, dan kurangnya perhatian dari keluarga dan masyarakat. Sehingga lanjut usia yang mengalami sakit dan lemah secara fisik, sulit untuk mengakses layanan kesehatan

karena keterbatasan dari segi tenaga dan biaya. Padahal kenyataan di lapangan beberapa lanjut usia di Kelurahan Sindang Jaya tinggal bersama keluarga tetapi kebutuhan dasarnya kurang terpenuhi. Namun, sebagian lanjut usia di Keluarahan Sindnag Jaya ada yang tinggal sendiri. Dengan demikian, diharapkan masyarakat melakukan perilaku prososial sehingga akan berdampak positif terhadap lanjut usia terlantar.

Berdasarkan penejelasan di atas, peneliti tertarik untuk mengetahui perilaku prososial masyarakat terhadap lanjut usia terlantar di Kelurahan Sindang Jaya. Peneliti ingin mengetahui perilaku masyarakat yang menunjang kesejahteraan lanjut usia yang mengalami ketelantaran. Hal ini, disebabkan karena lanjut usia dalam masyarakat biasanya diabaikan dan tidak dipedulikan karena dianggap lemah dan tidak mampu berkontribusi. Sesuai dengan latar belakang 
masalah, maka peneliti ingin melakukan penelitian dengan judul "Perilaku Prososial Masyarakat Terhadap Lanjut Usia Terlantar di Kelurahan Sindang Jaya Kecamatan Mandalajati Kota Bandung”.

Tujuan yang ingin dicapai dalam penelitian untuk mengetahui gambaran secara empiris tentang perilaku prososial masyarakat di Kelurahan Sidang Jaya. Mencakup bagaimana perilaku menolong, perilaku berbagi rasa, perilaku kerjasama, perilaku menyumbang dan perilaku memperhatikan kesejahteraan orang lain dalam hal ini lanjut usia terlantar yang dilakukan oleh masyarakat Kelurahan Sindang Jaya.

\section{METODE PENELITIAN}

Desain penelitian yang digunakan oleh peneliti adalah pendekatan kuantitatif dengan metode deskriptif. Penelitian deskriptif menurut (Nazir, 2017) adalah studi untuk menemukan fakta dengan interprestasi yang tepat.

Sumber data primer dalam penelitian ini adalah yaitu masyarakat yang menjadi Kepala Keluaraga (KK) di Kelurahan Sindang Jaya Kecamatan Mandalajati Kota Bandung dan bertempat tinggal satu Ruku Warga (RW) dengan lanjut usia terlantar yang memberikan jawaban terhadap pertanyaann penelitian. Sumber data sekunder dalam penelitian ini adalah sumber data yang didapatkan melalui studi dokumentasi terhadap buku-buku maupun literatur yang berkaitan dengan perilaku prososial masyarakat terhadap lanjut usia terlantar di Kelurahan Sindang Jaya Kecamatan mandalajati Kota Bandung.

Jenis penarikan sampel menggunakan probability sampling, dimana peneliti memberikan kesempatan yang sama bagi setiap unsur dalam populasi untuk dapat berpartisipasi menjadi responden. Jenis probability sampling yang digunakan adalah teknik stratified random karena pengambilan sampel memperhatikan strata yaitu wilayah yang terdapat lanjut usia terlantar dengan presisi $15 \%$.

Teknik pengumpulan data dengan penyebaran angket, dan studi dokumentasi. Alat ukur yang dugunakan adalah rating scale dan skala pengukurannya adalah skala ordinal. Menurut Sugiyono (2017), rating scale adalah data mentah yang diperoleh berupa anga kemudian ditafsirkan dalam bentuk kualitatif. Pernyataan yang digunakan adalah pernyataan positif dengan penskoran dimulai dari 4,3,2,1.

Pengujian validitas alat ukur yang digunakan dalam penelitian ini adalah validitas muka (face validity). Menurut Moh. Nazir (2017), validitas muka berhubungan dengan penelitian para ahli terhadap suatu alat ukur. Peneliti melakukan uji validitas alat ukur dengan berkonsultasi kepada ahli permasalahan yang diteliti sehingga instrumen penelitian benar- benar valid. Pengujian reliabilitas menggunakan software SPSS 25.0 Scale Reliability Analysis dengan model Cronbach's Alpha. Hasil uji reliabilitas instrumen menunjukkan angkat 0,963.

Teknik analisi data yang digunakan adalah statistik deskriptif, dengan tahapan sebagai berikut:

1. Menyajikan data, kegiatan pembuatan laporan hasil penelitian.

2. Editing, dilakukan dengan memberi identitas pada lembar instrumen, kemudian memeriksa lembar instrumen berdasar poin- poin dan jawaban yang 
tersedia.

3. Tabulasi, dilakukan dengan memasukkan data pada tabel- tabel tertentu dan mengatur angka-angka serta menghitungnya.

4. Kategorisasi instrumen hasil penelitian, menggunakan tiga kelas interval yaitu, tinggi, sedang, dan rendah.

5. Membuat garis kontinum, untuk menentukan posisi atau skor setiap aspek maupun variabel.

6. Penafsiran data, kegiatan dalam tahap ini adalah mencari penjelasan yang lebih luas tentang penemuan-penemuan.

7. Penarikan kesimpulan, kegiatan memberikan kesimpulan dari hasil analisis data sesuai dengan temuan penelitian yang dilakukan dengan menggunakan garis kontinum untuk melihat tingkat perilaku prososial masyarakat.

\section{HASIL UJI VALIDITAS RELIABILITAS}

DAN

\section{Uji Validitas}

Peneliti melakukan uji validitas alat ukur dengan berkonsultasi kepada ahli permasalahan yang diteliti sehingga instrumen penelitian benar-benar valid. Yang dimaksud ahli permasalahan yaitu pembimbing skripsi untuk menilai tingkat validitas instrumen yang digunakan baik validitas internal maupun eksternal.

\section{Uji Realibilitas}

Pengujian reliabilitas menggunakan software SPSS Scale Reliability Analysis dengan model Cronbach's Alpha. Jika hasil Cronbach's Alpha mendekati angka 1 maka instrument penelitian dikatakan reliabel.

\begin{tabular}{|c|c|}
\hline \multicolumn{2}{|c|}{ Reliability Statistics } \\
\hline $\begin{array}{c}\text { Cronbach's } \\
\text { Alpha }\end{array}$ & N of Items \\
\hline .963 & 33 \\
\hline
\end{tabular}

Hasil uji realibilitas yang dilakukan kepada 30 orang responden menggunakan SPSS Version 25.0 menunjukkan angka 0.963. Artinya, instrumen penelitian ini memiliki realibilitas yang sangat tinggi.

\section{HASIL PENELITIAN}

Kelurahan Sindang Jaya memiliki luas 77,84 ha dengan jumlah penduduk sebanyak 14.295 jiwa yang terdiri dari 12 RW dan 60 RT. Penelitian ini membahas tentang Perilaku Prososial Masyarakat Terhadap Lanjut Usia Terlantar di Kelurahan Sindang Jaya Kecamatan Mandalajati Kota Bandung. Jumlah lanjut usia terlantar di Kelurahan Sindang Jaya berjumlah 10 orang yang tersebar di 4 (empat) RW. Responden dalam penelitian ini merupakan Kepala Keluarga berjumlah $43 \mathrm{KK}$ yang berada di RW yang sama dengan lanjut usia terlantar.

\section{Karakteristik Responden Berdasarkan Usia}

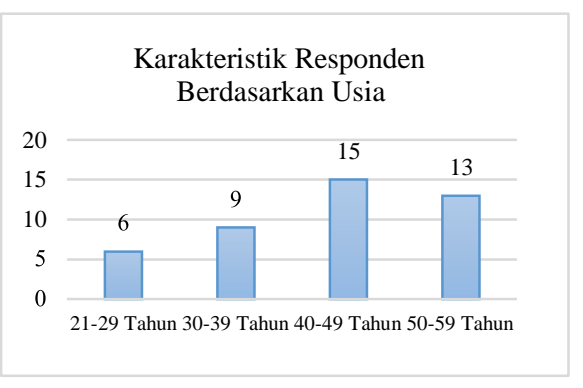

Gambar1.1 Karakteristik responden berdasarkan usia. Responden dalam penelitian ini 
dilihat dari usia paling banyak berada dalam rentang usia 40-49 tahun dan paling sedikit berada dalam rentang 2129 tahun.

\section{Karakteristik Responden Berdasarkan} Jenis Kelamin

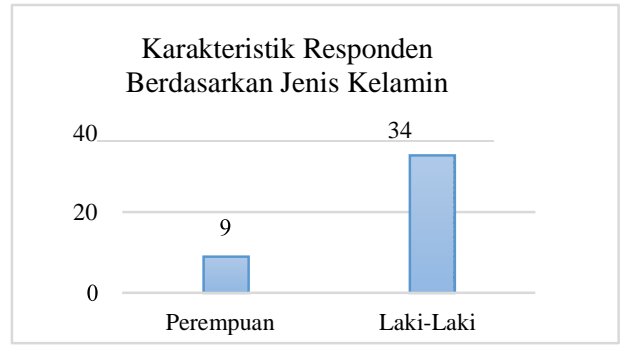

Gambar 1.2 Karakteristik responden berdasarakan jenis kelamin.

Responden penelitian mayoritas laki-laki sebanyak 40 orang. Sedangkan perempuan sebanyak 9 orang.

\section{Karakteristik Responden Berdasarkan} Pendidikan

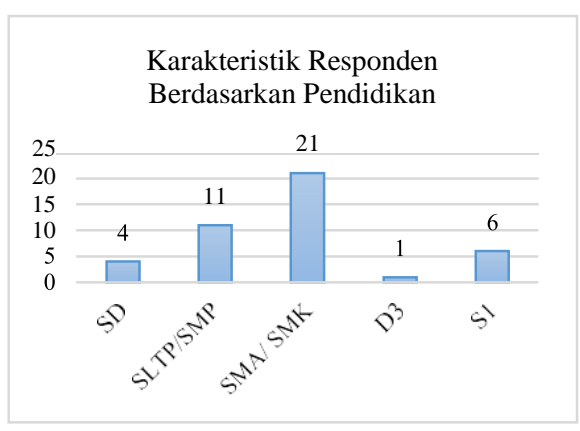

Gambar 1.3 karakteristik responden berdasarkan pendidikan

Responden paling banyak memiliki tingakat pendidikan SMA/ SMK sebanyak 21 orang. Sedangkan responden yang paling sedikit memiliki tingkat pendidikan D3 sebanyak 1 orang.

\section{Karakteristik Responden}

\section{Berdasarkan Pekerjaan}

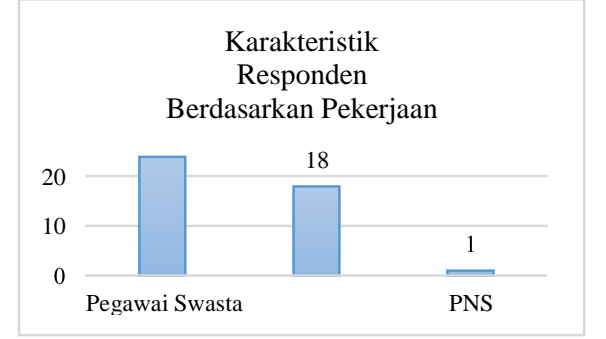

Gambar 1.4 Karakeristik responden berdasarkan pekerjaan.

Responden paling banyak bekerja sebagai pegawai swasta sebanyak 24 orang. Responden yang paling sedikit bekerja sebagai. Pegawai Negeri Sipil sebanyak 1 orang.

\section{Aspek Perilaku Menolong}

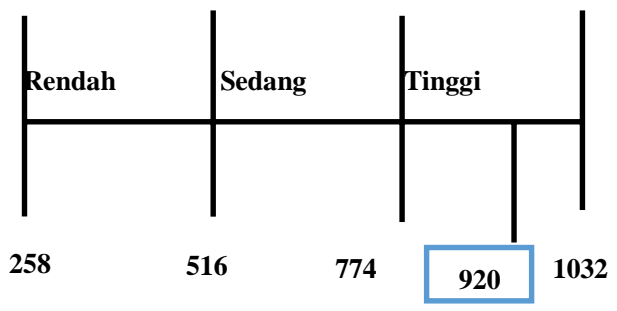

Gambar 1.5 Garis kontinum perilaku menolong masyarakat Sindang Jaya terhadap lanjut usia terlantar

Gambar di atas menunjukkan bahwa perilaku prososial masyarakat terhadap lanjut usia terlantar melalui perilaku menolong berada pada kategori tinggi dengan nilai 920 atau $89,15 \%$. Hal ini menunjukkan bahwa perilaku prososial masyarakat Kelurahan Sindang Jaya baik. 


\section{Aspek Perilaku Berbagi Rasa}

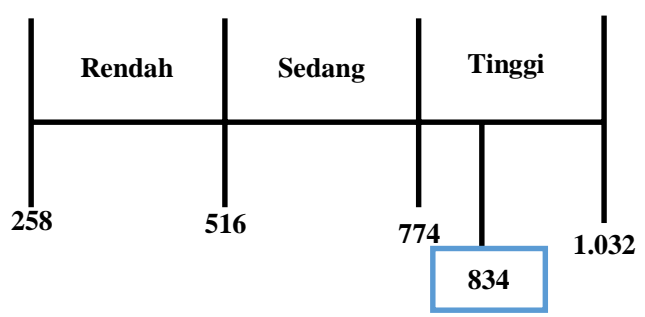

Gambar 1.6 Garis kontinum perilaku berbagi rasa masyarakat Sindang Jaya terhadap lanjut usia terlantar.

Gambar 1.6 di atas menunjukkan bahwa perilaku prososial masyarakat terhadap lanjut usia terlantar melalui perilaku berbagi rasa berada pada kategori tinggi dengan nilai 834 atau $80,81 \%$. Hal ini menunjukkan bahwa perilaku prososial masyarakat Kelurahan Sindang Jaya baik. Meskipun masih ada beberapa yang perlu ditingkatkan berdasarkan jawaban yang diberikan responden.

\section{Aspek Perilaku Kerjasama}

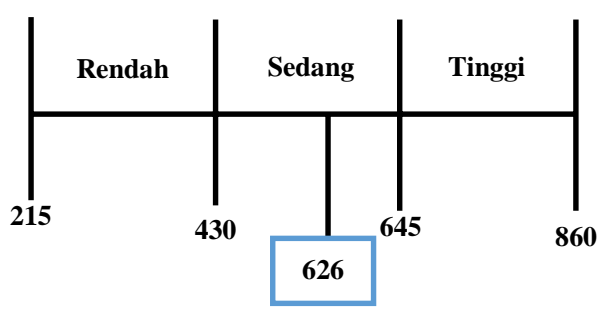

Gambar 1.7 Garis kontinum perilaku kersajasama masyarakat Sindang Jaya terhadap lanjut usia terlantar.

Gambar di atas menunjukkan bahwa perilaku prososial masyarakat terhadap lanjut usia terlantar melalui perilaku kerjasama berada pada kategori sedang dengan nilai 626 atau 72,79\%. Hal ini menunjukkan bahwa perilaku prososial masyarakat Kelurahan Sindang
Jaya cukup baik. Perilaku kerjasama di Kelurahan Sindang Jaya perlu ditingkatkan agar lanjut usia terlantar merasa diterima dan dihargai dalam masyarakat.

8. Aspek Perilaku Menyumbang

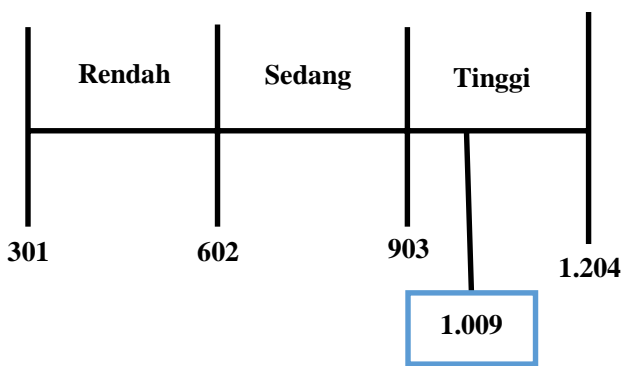

Gambar 1.8 Garis kontinum perilaku menyumbang masyarakat Sindang Jaya terhadap lanjut usia terlantar

Gambar 1.8 di atas menunjukkan bahwa perilaku prososial masyarakat terhadap lanjut usia terlantar melalui perilaku menyumbang berada pada kategori tinggi dengan nilai 1.009 atau $83,80 \%$. Hal ini menunjukkan bahwa perilaku prososial masyarakat Kelurahan Sindang Jaya baik

\section{Aspek Perilaku Memperhatikan} Kesejahteraan Orang Lain

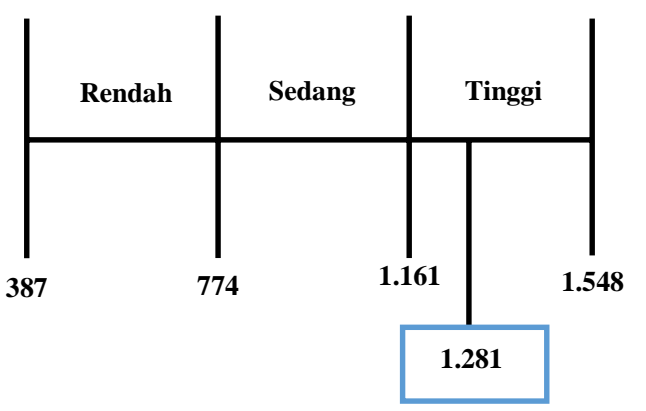

Gambar 1.9 Garis kontinum perilaku memperhatikan kesejahteran lanjut usia terlantar oleh masyarakat Sindang Jaya.

Gambar 1.9 di atas menunjukkan bahwa perilaku prososial masyarakat 
terhadap lanjut usia terlantar melalui perilaku memperhatikan kesejahteraan lanjut usia berada pada kategori tinggi dengan nilai 1.281 atau $82,75 \%$. Hal ini menunjukkan bahwa perilaku prososial masyarakat Kelurahan Sindang Jaya baik.

Rekapitulasi hasil penelitian perilaku prososial masyarakat terhadap lanjut usia terlantar di Kelurahan Sindang Jaya yang diukur melalui 5 (lima) aspek. Aspek perilaku prososial yang digunakan yaitu perilaku menolong, perilaku berbagi rasa, perilaku kerjasama, perilaku menyumbang, dan perilaku memperhatikan kesejahteraan orang lain diuraikan sebagai berikut:

a. Aspek menolong, nilai tertinggi 1.032, nilai terendah 258, skor hasil 920, termasuk kategori tinggi.

b. Aspek berbagi rasa, nilai tertinggi 1.032, nilai terendah 258, skor hasil 834, termasuk kategori tinggi.

c. Aspek kerjasama, nilai tertinggi 860 , nilai terendah 215, skor hasil 626, termasuk kategori sedang.

d. Aspek menyumbang, nilai tertinggi 1204, nilai terendah 301, skor hasil 1009, termasuk kategori tinggi.

e. Aspek memperhatikan kesejahteraan orang lain, nilai tertinggi 1548 , nilai terendah 387 , skor hasil 1281, termasuk kategori tinggi.

Rekapitulasi tersebut menunjukkan bahwa hasil skor perilaku prososial masyarakat terhadap lanjut usia terlantar di Kelurahan Sindang Jaya kecamatan Mandalajati berjumlah 4.670. Skor tertinggi diperoleh pada aspek memperhatiakan kesejahteraan orang lain dengan jumlah sebesar 1281, sedangkan skor terendah yakni pada aspek kerjasama dengan jumlah 626. Berikut garis kontinum perilaku prososial masyarakat terhadap lanjut usia terlantar di Kelurahan Sindang Jaya.

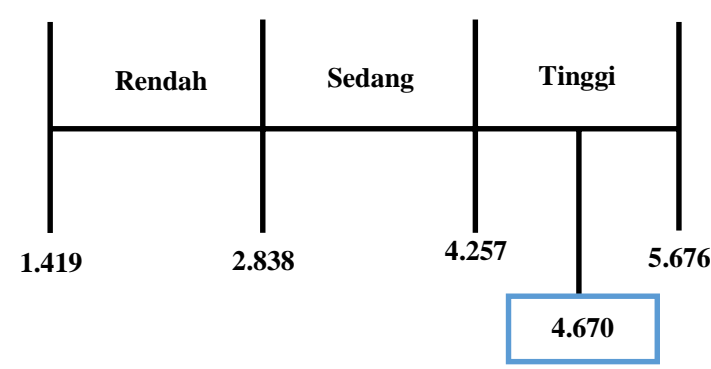

Gambar 1.10 Garis kontinum perilaku prosoial masyarakat terhadap lansia terlantar di kelurahan Sindang Jaya.

Gambar 1.10 menunjukkan bahwa perilaku prososial masyarakat terhadap lanjut usia terlantar di Kelurahan Sindang Jaya berada pada kategori tinggi dengan nilai 4.670. Hal ini menunjukkan bahwa perilaku prososial masyarakat Kelurahan Sindang Jaya baik.

Hasil penelitian perilaku prososial masyarakat terhadap lanjut usia terlantar di Kelurahan Sindang Jaya berada dalam kategori baik atau tinggi. Hal ini didasari pada setiap aspek perilaku yang diteliti termasuk dalam kategori tinggi. Akan tetapi, secara keseluruhan terdapat beberapa masalah yang dialami. Masalah merupakan sesuatu yang bertentangan dengan apa yang diharapkan.

Masalah yang ditemukan dalam penelitian tentang perilaku prososial masyarakat terhadap lanjut usia terlantar di Kelurahan Sindang Jaya yaitu masih kurangnya perilaku kerjasama masyarakat dengan lanjut usia terlantar, dimana hasil penelitian menunjukkan 
bahwa aspek kerjasama berada dalam kategori sedang. Dimana, masyarakat memandang bahwa lanjut usia sebagai individu yang sudah rentan, lemah, dan tidak dapat berkontribusi serta berpartisiapasi dalam melakukan aktivitas secara bersama-sama. Sedangkan, pada kenyataannya lanjut usia memiliki hak untuk ikut serta dalam kegiatan yang ada di masyarakat. Kesempatan yang diberikan kepada lanjut usia dalam berpartisiapasi pada kegiatan yang ada merupakan bentuk penghargaan dan pengakuan masyarakan yang menunjukkan lanjut usia bagian dari masyarakat.

Perilaku prososial yang tinggi perlu untuk dipertahankan bahkan ditingkatkan lagi. Perilaku prososial masyarakat pada aspek kerjasama masih kurang dan perlu untuk ditingkatkan. Perilaku kerjasama yang masih kurang disebabkan oleh pengetahuan masyarakat yang minim tentanng hak dan kebutuhan lanjut usia. Pengetahuan yang masih minim menyebabkan masyarakat kurang memahami kondis, hak, dan kebutuhan lanjut usia khusunyalanjut usia terlantar. Sehingga masyarakat perlu diberikan kesadaran dan pemahaman mengenai hak dan kebutuhan lanjut usia supaya masyarakat lebih peduli dan tanggap akan kondisi dan cara penanganan permasalahan yang dialami oleh lanjut usia. Masyarakat dan lanjus usia membutuhkan suatu kelompok atau kegiatan yang dapat dilakukan secara bersama-sama dan mempererat hubungan antar kedua pihak. Kegiatan atau kelompok yang dibentuk dapat menajdi sarana untuk meningkatkan perilaku kerjasamadan perilaku prososial lainnya.

\section{KESIMPULAN}

Penelitian yang berjudul tentang Perilaku Prososial Masyarakat Terhadap Lanjut Usia Terlantar di Kelurahan Sindang Jaya Kecamatan Mandalajati Kota Bandung. Penelitian ini berdasar pada penelitian terhadap Kepala Keluarga (KK) yang berada di wilayah yang sama dengan lanjut usia terlantar. Penentuan sampel penelitian menggunakan teknik simple random sampling dengan presisi $15 \%$, sehingga jumlah responden sebanyak 43 KK. Hasil penelitian yang dilakukan dapat disimpulkan bahwa perilaku prososial masyarakat terhadap lanjut usia terlantar di Kelurahan Sindang Jaya termasuk pada kategori tinggi. Hal ini terlihat dari skor pada 4 aspek penelitian berda dalam kategori tinggi dan 1 aspek berada dalam kategori sedang. Sehingga, masih membutuhkan beberapa upaya untuk meningkatkannya.

Program yang diusulkan peneliti yaitu "Peningkatan Perilaku Prososial Masyarakat untuk Kesejahteraan Lanjut Usia di Kelurahan Sindang Jaya". Implementasi program ini dilakukan melalui kegiatan penyuluhan sosial tentang hak, kebutuhan, dan permasalahan lanjut usia dan pembentukan kelompok pengajian di RW tempat tinggal lanjut usia di Kelurahan Sindang Jaya.

\section{DAFTAR PUSTAKA}

Bartal, Daniel. 2007. Perilaku Prososial. Terjemahan:Sekolah Pascasarjana Universitas Pendidikan Indonesia, Bandung. Beni, Romanus. (2001). Kesejahteraan Lanjut Usia Masa Depan, 
Sehat, Produktif dan Mandiri. Fakultas Ekonomi Universitas Indonesia.

Burhan Bungin. 2011. Metodologi Penelitian Kuantitatif. Jakarta: Kencana.

Edi Suharto. 2009. Membangun Masyarakat Memberdayakan Rakyat. Bandung: PT Refika Aditama.

Hurlock. Elizabeth B. 2012. Psikologi Perkembangan: Suatu Pendekatan Sepanjang Kehidupan. Terjemahan: Istiwidayanti dan Soedjarwo. Jakarta: Erlangga.

Khoiruddin Bashori.(2017). Menyemai Perilaku Prososial di Sekolah. Jurnal Pendidikan, 1,(67-69, 69-73).

Lilik Azizah.2011.Keperawatan Lanjut Usia. Edisi ke 1. Yogyakarta: Graha Ilmu.

M. Nazir. 2017. Metode Penelitian. Bogor: Ghalia Indonesia.

Nashori. 2008. Psikologi Sosial Islami. Edisi ke 1. Bandung: PT. Refika Aditama.

Robert A, Baron dan Donn Byrne. 2003. Psikologi Sosial. Terjemahan oleh Ratna Djuwita. Jakarta: Erlangga.

Peraturan Daerah Kota Bandung tentang Kota Ramah Lanjut Usia Tahun 2020

Peraturan Menteri Sosial Republik Indonesia Nomor 08 Tahun 2012 tentang Pedoman Pengelolahan dan Pendataan Penyandang Masalah Kesejahteraan Sosial (PMKS) dan Potensi Sumber Kesejahteraan Sosial (PSKS).

Peraturan Menteri Sosial Republik Indonesia Nomor 12 Tahun 2013 tentang Program Asistensi Lanjut Usia Terlantar.

Siti Maryam. 2008.Mengenal Lanjut Usia dan Penangannya. Jakarta: Salemba Medics.

Sugiyono. 2017. Metode Penelitian Kualitatif, Kuantitatif, $R \& D$. Bandung: Alfabeta.

Suharsimi Arikunto. 2013. Prosedur Penelitian: Suatu Pendekatan Praktik. Jakarta: Rineka Cipta.

Tri Dayakisni dan Hudaniah. 2009.Psikologi Sosial. Malang: UMM Press. Departemen Pendidikan Nasional.

Tody Lalenoh. 1996. Lanjut Usia danUsia
Lanjut. Bandung: Sekolah Tinggi Kesejahteraan Sosial Bandung.

Undang-Undang Nomor 13 Tahun 1998 tentang Kesejahteraan Lanjut Usia.

Yesmil Anwar dan Adang. 2013. Sosiologi untuk Universitas. Bandung PT Refika Aditama.

Zastrow, Charles. 2017. Introduction to Social Work and Social Welfare: Empowering People. Canada: Nelson Education Ltd.

\section{Internet}

Badan Pusat Statistika. 2019. Statistika Penduduk Lanjut Usia 2019.

https://www.bps.go.id/publication/2019/ 
